\title{
EFFECT ON CHILDREN PLAY ROOM TYPOLOGY PATTERN PLAY ACTIVITY BEHAVIOR OF CHILDREN CASE STUDY: RUSUNAWA WEST JATINEGARA, EAST JAKARTA $A N D$ RUSUNAWA CIGUGUR, CIMAHI, WEST JAVA
}

\author{
${ }^{1}$ Deti Febriyana. ${ }^{2}$ Dr. Ir. Y. Basuki Dwisusanto, M. Sc. \\ ${ }^{1}$ Student in the Bachelor's (S-1) Study Program in Architecture \\ at Parahyangan Catholic University \\ ${ }^{2}$ Senior lecturer in the Bachelor's (S-1) Study Program in Architecture \\ at Parahyangan Catholic University
}

\begin{abstract}
Fulfilling the ever-increasing need for residential areas in a brief period of time has triggered the remarkable immaturity that can be observed in the development of urban planning. Multi-storied apartments may form a solution for the problem of meeting this demand. However, their design fails to pay sufficient attention to the necessary means of social interaction, especially in providing a suitable area for children's playgrounds. This study aims to explore the various typologies for children's playgrounds, and the influence they exert on the pattern of play activities. This research study may stimulate the effort to improve the quality of residential areas and the space reserved for children's playgrounds, focusing on the low-rent apartments known as rusunawa found in West Jatinegara, East Jakarta and those situated in Cigugur, Cimahi, West Java. In the latter there was no playground available for children, so that the local residents' children finally created a new spot not originally intended for that purpose, whereas the former had already provided one. The samples selected consist of both boys and girls whose age range is between 2-12 years old. The theoretical background literature deals with home-range, behavioral setting, personal space and children's play activities. This research study yields the conclusion that the spatial typology does not affect the pattern of the children's play activities, and furthermore no difference was found in the behavioral pattern of the children's play activities between the two neighborhoods examined. The behavioral pattern of the children's play activities turned out to be just the same. Moreover, in both study locations, it was found that the older the children, the more capacious the personal space they require tends to be.
\end{abstract}

Keywords: Spatial Typology, Children's Play Activities, Home-range, Behavioral Setting

\footnotetext{
${ }^{1}$ Corresponding Author:detysirath@gmail.com
} 


\title{
PENGARUH TIPOLOGI RUANG BERMAIN ANAK TERHADAP POLA PERILAKU AKTIVITAS BERMAIN ANAK STUDI KASUS: RUSUNAWA JATINEGARA BARAT, JAKARTA TIMUR DAN RUSUNAWA CIGUGUR, CIMAHI, JAWA BARAT
}

\author{
${ }^{1}$ Deti Febriyana. ${ }^{2}$ Dr. Ir. Y. Basuki Dwisusanto, M. Sc. \\ ${ }^{1}$ Mahasiswa S1 Program Studi Arsitektur Universitas Katolik Parahyangan. \\ ${ }^{2}$ Dosen Pembimbing S1 Program Studi Arsitektur Universitas Katolik Parahyangan.
}

\begin{abstract}
Abstrak- Pemenuhan kebutuhan tempat tinggal yang meningkat dalam waktu yang singkat mengakibatkan ketidakmatangan dalam perencanaan pengembangan tata ruang kota. Rumah susun merupakan solusi untuk menyelesaikan masalah kebutuhan tempat tinggal tersebut. Perancangan rumah susun kurang memperhatikan kebutuhan sarana interaksi sosial, terutama area bermain anak. Anak-anak bermain pada tempat yang kadang kurang layak sebagai ruang bermain seperti ruang sirkulasi dan ruang publik komersil. Penelitian ini bertujuan untuk mengetahui jenis tipologi ruang bermain anak, dan pengaruh tipologi ruang bermain anak terhadap pola aktivitas bermainnya. Penelitian ini diharapkan dapat membantu dalam pertimbangan usaha peningkatan kualitas ruang tinggal dan ruang bermain anak terutama dalam skala lingkungan rumah susun. Penelitian dilakukan pada Rusunawa Jatinegara Barat, Jakarta Timur dan Rusunawa Cigugur, Cimahi. Di Rusunawa Cigugur, tidak terdapat area bermain untuk anak, sehingga anak-anak warga Rusunawa Cigugur mencari dan menciptakan tempat baru yang bukan ditujukan untuk aktivitas bermain. Sementara, Rusunawa Jatinegara Baratsudah tersedia area bermain. Sampel yang dipilih adalah anak laki-laki dan perempuan dengan rentang umur 2-12 tahun. Penelitian dilakukan dengan observasi aktivitas bermain anak dan kajian teoritik mengenai home-range, seting perilaku, ruang personal dan aktivitas bermain anak. Setelah melakukan penelitian ini, didapatkan hasil bahwa tipologi ruang tidak berpengaruh terhadap pola aktivitas bermain anak, dan tidak terdapat perbedaan pola perilaku aktivitas bermain anak di antara kedua rusun tersebut. Pola perilaku aktivitas bermain yang terjadi sama saja. Selain itu, di kedua lokasi studi juga didapatkan bahwa semakin bertambahnya usia seorang anak, ruang personal yang dibutuhkan juga akan semakin luas.
\end{abstract}

Kata kunci: Tipologi Ruang, Aktivitas Bermain Anak, Home-range, Seting Perilaku.

\section{PENDAHULUAN}

Rumah susun adalah salah satu dari tipe permukiman terencana. Melihat dari segi efisiensi tanah yang digunakan dan banyaknya kepala keluarga yang bisa menetap didalamnya, rumah susun, dianggap sebagai jawaban akan kebutuhan tempat tinggal yang semakin meningkat drastis. Rumah susun dapat difungsikan untuk dua jenis penduduk, yaitu untuk penduduk yang kurang mampu dan penduduk yang terprogram. Yang dimaksud terprogram adalah, rumah susun tersebut ditujukan untuk warga yang terkena dampak dari suatu kejadian/peristiwa, contohnya relokasi.

Hanya saja dikarenakan rumah susun lebih ditujukan kepada sebuah kelompok besar, banyak arsitek atau perancang yang membangun rumah susun kurang memperhatikan sarana dan prasarana yang ada di dalamnya. Para arsitek cenderung hanya memikirkan tampilan luar/fasad bangunannya. Ditambah lagi, bila peran ekonomi bangunan untuk mencari keuntungan sudah ikut ambil andil di dalamnya. Perhitungan akan rasio luas yang bisa dihuni dan bisa menghasilkan keuntungan, harus sebisa mungkin mencapai nilai maksimal, sehingga banyak ruang-ruang yang seharusnya berpotensi sebagai ruang komunal yang baik justru dihilangkan demi keuntungan semata. 
Padahal, aktivitas bermain sangat penting bagi anak usia dini karena melalui bermain anak-anak dapat mengembangkan aspek-aspek perkembangan anak. Aspek-aspek tersebut antara lain aspek fisik, sosial, emosional dan kognitif. Bermain dapat mengembangkan aspek fisik/motorik yaitu melalui permainan motorik kasar dan halus, kemampuan mengontrol anggota tubuh, belajar keseimbangan, kelincahan, koordinasi mata dan tangan, dan lain sebagainya. Adapun dampak jika anak tumbuh dan berkembang dengan fisik/motorik yang baik maka anak akan merasa lebih percaya diri, memiliki rasa nyaman, dan memiliki pemikiran yang lebih positif.

Contoh kasus yang diambil adalah Rusunawa Cigugur, Cimahi yang tidak memiliki tempat/ruang bermain khusus untuk anak, sehingga anak-anak warga Rusunawa Cigugur mencari tempat baru yang bukan fungsinya. Dilain hal, Rusunawa Jatinegara Barat hadir dengan inovasi desain berupa sebuah taman bermain khusus untuk anak-anak. Taman bermain ini dibangun dengan dasar kebutuhan untuk aktivitas bermain anak-anak.

Yang ingin diteliti disini adalah, pola aktivitas bermain anak di kedua rusun, jenis tipologi area bermain anak dan pengaruh tipologi ruang bermain anak terhadap pola perilaku aktivitas bermain anak.

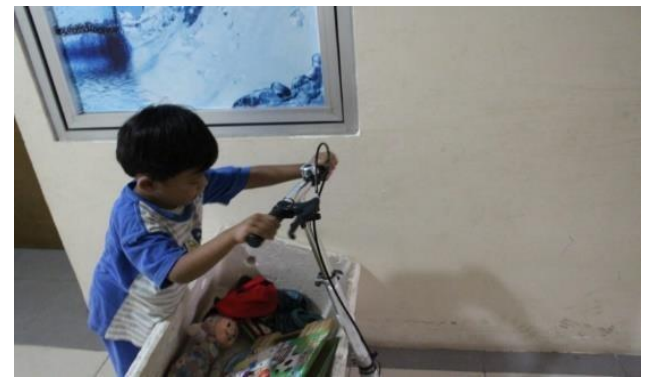

Figur 1. Anak Bermain di Koridor Rusunawa Jatinegara Barat

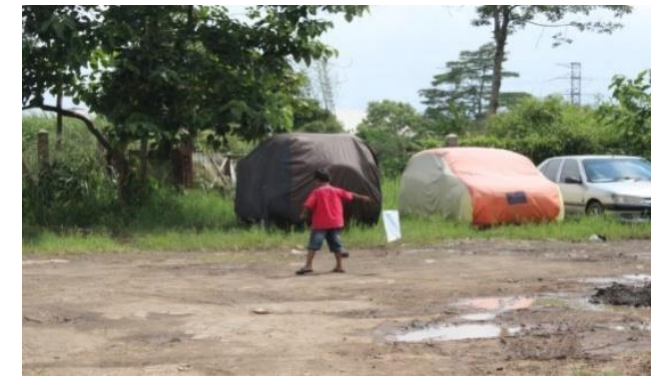

Figur 2. Anak Bermain Layangan di Area Parkir Mobil Rusunawa Cigugur, Cimahi

\section{KAJIAN TEORI}

\subsection{ANAK DAN KEBUTUHAN BERMAIN}

\subsubsection{KONSEP BERMAIN}

Bermain adalah kegiatan dimana seorang anak dapat melakukan apa yang dia inginkan, kapan dan dimana dia melakukanya. Bermain merupakan seluruh aktivitas anak termasuk bekerja dan merupakan cara tersendiri bagi anak untuk mengenal dunianya. Bermain tidak hanya untuk sekedar mengisi waktu tetapi juga dapat merangsang perkembangan sensorimotorik, perkembangan sosial, perkembangan kreativitas, perkembangan kesadaran diri, perkembangan moral dan bermain sebagai terapi.

\subsubsection{FUNGSI SOSIAL DALAM BERMAIN}

Bermain adalah suatu tradisi dan bentuk dari aturan serta perilaku yang terwujud dalam lingkungan sosial. Orang dewasa berpengaruh terhadap budaya dan nilai sosial dalam bermain yang akan diteruskan oleh anak. Jelas terlihat bahwa bermain menjadi suatu cara untuk meneruskan nilai dan norma budaya dari satu generasi ke generasi berikutnya. 


\subsubsection{FUNGSI PSIKOLOGI DALAM BERMAIN}

Bermain adalah sarana belajar anak yang paling mutlak yang berkembang sejalan dengan pendewasaannya melalui proses belajar yang berkesinambungan tanpa atau dengan sekolah formal. Bermain merupakan cara untuk mengembangkan kemampuan berpikir atau sebagai cara agar anak mudah untuk mengerti sesuatu. Dalam pengembangan ilmu psikologi saat ini terdapat faktor yang mempengaruhi pengembangan mental seseorang yaitu faktor keturunan dan faktor lingkungan.

\subsection{KARATERISTIK RUANG BERMAIN ANAK}

Menurut Mitsuru Senda (1993), aspek-aspek pembentuk ruang bermain anak dibagi menjadi berikut:

\subsubsection{TEMPAT BERMAIN}

Tempat bermain merupakan ruang yang digunakan oleh individu atau kelompok untuk melakukan aktivitas bermain. Mitsuru Senda dalam bukunya mengklasifikasikan tempat untuk bermain menjadi 6 tipe, yaitu:

(1) Ruang Alami

Merupakan ruang yang melibatkan banyak makhluk hidup seperti orang, hewan dan tumbuhan. Hal tepenting yang akan dipelajari ketika bermain disini yaitu emosi dan faktafakta dari hidup.

(2) Ruang Terbuka

Merupakan suatu ruangan yang besar dan kosong serta membebaskan anak untuk menghabiskan energinya.

(3) Ruang Jalan

Merupakan tempat dimana anak akan bertemu dengan individu atau kelompok lain ketika ia membuat suatu gerakan.

(4) Ruang Anarki

Merupakan ruang yang tidak terdesain, ruang dengan banyak barang-barang rongsokan, ruang disekitar pabrik. Ruang-ruang tersebut dapat merangsang kreativitas anak-anak.

(5) Ruang Tersembunyi

Merupakan ruang dimana anak dapat bersembunyi. Ruang ini dapat memacu adrenalin dan merupakan ruang yang paling disenangi oleh anak-anak.

\subsubsection{WAKTU BERMAIN}

Anak-anak akan bermain dimana saja dan kapan saja yang mereka inginkan. Contohnya saja ketika seorang anak sedang menunggu ibunya menyediakan makanan, anak akan memainkan garpu dan sendoknya lalu mulai mengetuk-ngetukannya ke meja, sehingga menghasilkan nada yang ada di pikiran mereka. Hal ini menunjukan bahwa bagi anak belajar dan bekerja merupakan waktu untuk mereka bermain.

\subsubsection{TEMAN BERMAIN}


Teman bermain merupakan subyek yang menemani anak dalam melakukan aktivitas bermain. Anak dapat bermain seorang diri, bermain dengan teman dekatnya saja, atau bermain dengan sekelompok anak lainnya. Hal ini bergantung kepada jenis permainan yang akan dimainkan.

\subsubsection{JENIS PERMAINAN}

Menurut Hurlock (1995), jenis kegiatan bermain dibagi menjadi 2 yaitu:

(1) Kegiatan Bermain Aktif

Kegiatan bermain aktif terjadi pada masa awal anak-anak. Macam-macam permainan yang termasuk kedalam kategori bermain aktif antara lain seperti permainan fisik, permainan kreatif, serta permainan indera.

Kegiatan Bermain Pasif

Kegiatan bermain pasif biasa terjadi pada masa akhir anak-anak. Macam-macam permainan yang termasuk kedalam kategori permainan pasif yaitu permainan sosial dan permainan ketenangan.

\subsubsection{ALAT PERMAINAN}

Permainan untuk anak haruslah permainan yang mendidik/edukatif, yang berguna untuk mengembangkan aspek motorik, bahasa, kecerdasan dan sosialisasi anak. Beberapa syarat yang perlu diperhatikan dalam menciptakan atau memilih permainan edukatif diantaranya:(1) Desain Mudah dan Sederhana (2) Multifungsi (3) Menarik (4) Berukuran Besar (5) Awet dan Sesuai Kebutuhan (6) Mendorong Anak untuk Bermain Bersama dan Berbagi (7) Mengembangkan Daya Fantasi (8) Mengandung Adrenalin.

\subsection{SETING PERILAKU}

Menurut Roger Barker, seting perilaku adalah konsep kunci bagi analisis perilaku manusia dalam arsitekturii. Seting perilaku memiliki arti sebagai suatu kombinasi yang seimbang antara unsur-unsur pembentuknya, antara lain:

Tabel 1. Unsur-unsur Pembentuk Seting Perilaku

(sumber: Dewiyanti, Dhini (2000). Tesis Magister Arsitektur. Karateristik Ruang Bermain Anak)

\begin{tabular}{|c|l|l|l|}
\hline NO. & \multicolumn{1}{|c|}{ UNSUR } & \multicolumn{1}{c|}{ PENJELASAN } & \multicolumn{1}{c|}{ JENIS } \\
\hline 1 & $\begin{array}{l}\text { Pola Perilaku Tetap } \\
\text { (Standing Patterns of } \\
\text { Behavior) }\end{array}$ & $\begin{array}{l}\text { Pola perilaku aktivitas yang } \\
\text { berulang. } \\
\text { Pola ini tidak bergantung pada } \\
\text { objek saja melainkan terhadap } \\
\text { konfigurasi dari seluruh bagian } \\
\text { di dalam } \\
\text { seting }\end{array}$ & $\begin{array}{l}\text { Perilaku Emosional } \\
\text { Merilaku } \\
\text { Masalah } \\
\text { Aktivitas Motorik } \\
\text { Interaksi Interpersonal } \\
\text { Manipulasi Objek }\end{array}$ \\
\hline
\end{tabular}




\begin{tabular}{|c|l|l|l|}
\hline 2 & $\begin{array}{l}\text { Layout Khusus } \\
\text { Lingkungan } \\
\text { (Circumjacent } \\
\text { Milieu })\end{array}$ & $\begin{array}{l}\text { Tata lingkungan berupa batas } \\
\text { fisik dan bersifat sementara } \\
\text { dari suatu seting yang } \\
\text { berkaitan dengan pola } \\
\text { perilaku. }\end{array}$ & $\begin{array}{l}\text { Objek yang berfungsi sebagai } \\
\text { batas spasial. } \\
\text { Objek yang berfungsi sebagai } \\
\text { pendukung aktivitas. }\end{array}$ \\
\hline 3 & $\begin{array}{l}\text { Hubungan Timbal } \\
\text { Balik } \\
\text { (Synomorphy) }\end{array}$ & $\begin{array}{l}\text { Hubungan antara pola aktivitas } \\
\text { dengan ruang yang dibatasi } \\
\text { secara selaras sehingga } \\
\text { menghasilkan } \\
\text { keharmonisan } \\
\text { kecocokan yang dapat } \\
\text { dipengaruhi oleh latar } \\
\text { belakang individu manusia. }\end{array}$ \\
& $\begin{array}{l}\text { Periode } \\
\text { Tertentu } \\
\text { Spesific Period) }\end{array}$ & $\begin{array}{l}\text { Suatu seting dapat stabil bila } \\
\text { dilakukan dalam periode } \\
\text { waktu tertentu. }\end{array}$ & \\
\hline 4
\end{tabular}

\subsection{HOME RANGE}

Home range merupakan titik-titik yang dibentuk dari rutinitas individu pada periode waktu tertentu dan tidak dapat dibatasi jangkauan kegiatannya. Titik-titik tersebut saling berhubungan dan membentuk jalur. Dalam pembelajaran mengenai aktivitas kegiatan manusia, kata orbit biasa digunakan sebagai tolak ukur yang sama dari home range.

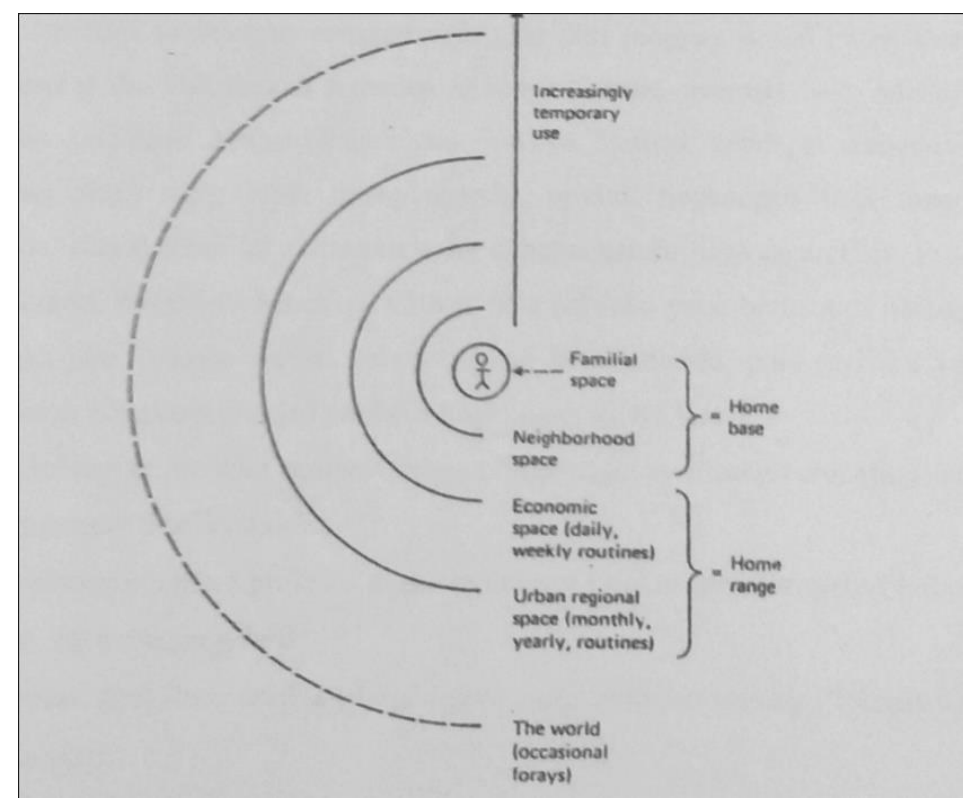

Figur 3. Hierarki Ruang Sosial (Chombart de Lauwe,1965) 


\subsection{RUANG PERSONAL (PERSONAL SPACE)}

Joyce Marcella $^{\text {iv }}$, mengklasifikasikan ruang personal dan hubungannya dengan desain arsitektur, dalam dua ruang, yaitu:

(1) Ruang Sosiopetal (Sociopetal)

Ruang sosiopetal merujuk kepada suatu tatanan yang mampu memfasilitasi interaksi sosial.

(2) Ruang Sosiofugal (Sociofugal)

Sementara, ruang sosiofugal adalah kebalikan dari ruang sosiopetal. Ruang sosiofugal mampu mengurangi terjadinya interaksi.

Fokus penelitian akan berpusat pada tipologi ruang dan isu pola aktivitas anak di Rusunawa Jatinegara Barat dan Cigugur. Isu tersebut terlahir dari fenomena dimana anakanak di Rusunawa Cigugur menciptakan tempat-tempat bermain sendiri di area publik/komersil, sementara anak-anak di Rusunawa Jatinegara Barat yang sudah memiliki area bermain khusus justru lebih memilih untuk bermain di tempat lain yang tidak difungsikan untuk aktivitas tersebut.

Dengan menggunakan teori-teori mengenai jenis-jenis tipologi ruang, home-range, homebase, seting perilaku dan ruang personal, diharapkan dapat diketahui apabila tipologi sebuah ruang bermain anak yang sama ataupun berbeda memiliki andil yang besar dalam pola aktivitas bermain anak, atau tidak.

\section{ANALISIS PENGARUH TIPOLOGI RUANG TERHADAP POLA PERILAKU AKTIITAS BERMAIN ANAK}

Konsep ini menggunakan data home range sebagai jangkauan ruang makro untuk memperlihatkan kesinambungan antara jarak ruang aktivitas bermain anak dengan pola aktivitas bermainnya sebagai suatu rangkaian seting yang terdapat dalam lokasi studiiii .

Jangkauan yang diambil untuk mendasari aktivitas bermain anak-anak warga Rusunawa Jatinegara Barat dan Rusunawa Cigugur dibagi berdasarkan tipologi ruang yang terdapat di rusunawa yaitu: (1) Home Range A di lantai rumah (0-25m) (2) Home Range B di area sekitar blok rusun (25-100m) (3) Home Range C di area blok (100-250m), dan (4) Home Range D di area luar rusun $(>250 \mathrm{~m})$.

Sementara, klasifikasi tempat bermain didasarkan pada teori dari Mitsuru Senda ${ }^{i}$, yang dibagi menjadi ruang alami, ruang terbuka, ruang jalan, ruang anarki, dan ruang tersembunyi. 


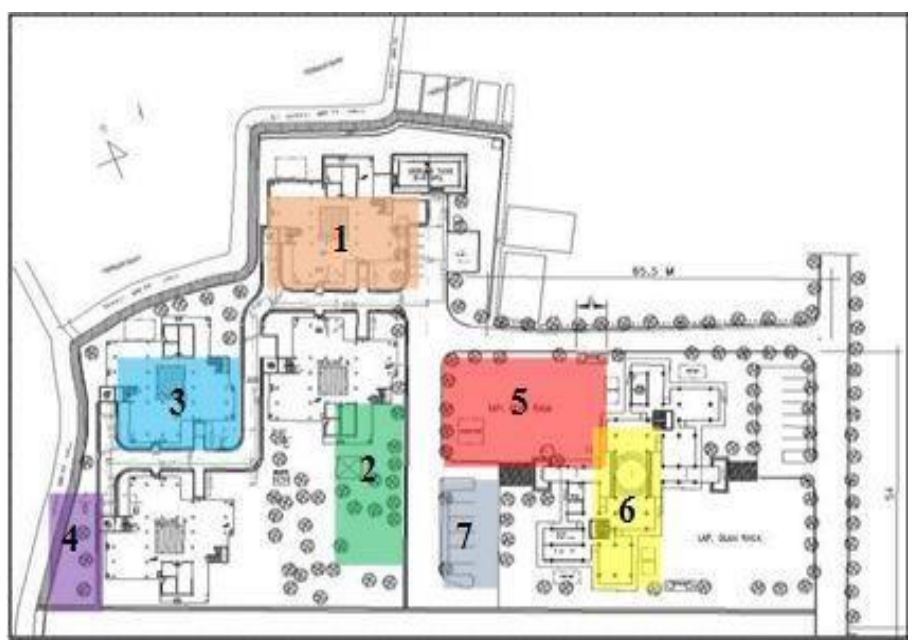

Figur 4. Titik-titik Ruang Aktivitas Bermain Anak Di Rusunawa Cigugur, Cimahi

(Sumber: UPT Rusunawa Cigugur, Cimahi)

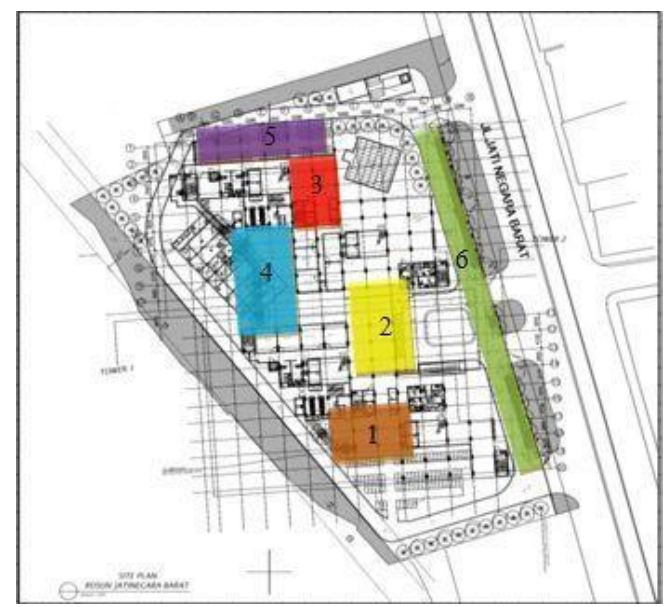

Figur 5. Titik-titik Ruang Aktivitas Bermain Anak Di Jatinegara Barat (Sumber: UPT Rusunawa Jatinegara Barat)

\subsection{KLASIFIKASI RUANG}

\subsubsection{RUANG TERBUKA}

Mitsuru Senda ${ }^{\text {ii }}$ mendeskripsikan bahwa ruang terbuka merupakan suatu ruangan yang besar dan kosong serta dapat membebaskan anak untuk menghabiskan energinya.

Tabel 2. Klasifikasi Tipologi Ruang Terbuka di Rusunawa Cigugur

\begin{tabular}{|c|c|c|c|c|}
\hline $\begin{array}{c}\text { Jenis } \\
\text { Ruang }\end{array}$ & $\begin{array}{l}\text { Lokasi } \\
\text { Ruang }\end{array}$ & Aktivitas & Tipologi & Dokumentasi \\
\hline $\begin{array}{c}\text { Lapangan } \\
\text { Terbuka }\end{array}$ & Lokasi 5 & $\begin{array}{c}\text { Permainan } \\
\text { Aktif }\end{array}$ & $\begin{array}{l}\text { Ruang } \\
\text { Terbuka }\end{array}$ & \\
\hline $\begin{array}{c}\text { Lantai } \\
\text { Dasar Blok E- } \\
\text { D }\end{array}$ & Lokasi 6 & $\begin{array}{l}\text { Permainan } \\
\text { Aktif }\end{array}$ & & 4 \\
\hline
\end{tabular}


Tabel 3. KlasifikasiTipologi Ruang Terbuka di Rusunawa Jatinegara Barat

\begin{tabular}{|c|c|c|c|c|}
\hline $\begin{array}{r}\text { Jenis } \\
\text { Ruang }\end{array}$ & $\begin{array}{l}\text { Lokasi } \\
\text { Ruang }\end{array}$ & Aktivitas & Tipologi & Dokumentasi \\
\hline $\begin{array}{l}\text { Lobby } \\
\text { Rusun }\end{array}$ & Lokasi 2 & $\begin{array}{c}\text { Permainan } \\
\text { Pasif dan } \\
\text { Aktif }\end{array}$ & $\begin{array}{l}\text { Ruang } \\
\text { Terbuka }\end{array}$ & \\
\hline $\begin{array}{l}\text { Ruang } \\
\text { Transisi }\end{array}$ & Lokasi 3 & $\begin{array}{c}\text { Permainan } \\
\text { Pasif dan } \\
\text { Aktif }\end{array}$ & & \\
\hline $\begin{array}{l}\text { Area } \\
\text { Bermain } \\
\text { Anak }\end{array}$ & Lokasi 4 & $\begin{array}{c}\text { Permainan } \\
\text { Pasif dan } \\
\text { Aktif }\end{array}$ & & \\
\hline
\end{tabular}

\subsubsection{RUANG JALAN}

Mitsuru Senda mendeskripsikan bahwa ruang jalan adalah tempat dimana anak akan bertemu dengan individu atau kelompok lain ketika ia membuat suatu gerakan seperti bermain sepeda, bermain sepatu roda, dll.

Tabel 4. Klasifikasi Tipologi Ruang Jalan di Rusunawa Cigugur

\begin{tabular}{|c|c|c|c|c|}
\hline $\begin{array}{c}\text { Jenis } \\
\text { Ruang }\end{array}$ & $\begin{array}{l}\text { Lokasi } \\
\text { Ruang }\end{array}$ & Aktivitas & Tipologi & Dokumentasi \\
\hline $\begin{array}{c}\text { Area } \\
\text { Sirkulasi }\end{array}$ & $\begin{array}{c}\text { Lokasi 1: } \\
\text { Koridor } \\
\text { Rusun }\end{array}$ & $\begin{array}{c}\text { Permainan } \\
\text { Pasif }\end{array}$ & $\begin{array}{c}\text { Ruang } \\
\text { Jalan }\end{array}$ & $\overline{1}$ \\
\hline $\begin{array}{l}\text { Area } \\
\text { Parkir } \\
\text { Mobil }\end{array}$ & $\begin{array}{c}\text { Lokasi 7: } \\
\text { Parkir } \\
\text { Rusunawa }\end{array}$ & $\begin{array}{c}\text { Permainan } \\
\text { Aktif }\end{array}$ & & \\
\hline
\end{tabular}




\begin{tabular}{|c|c|c|c|c|}
\hline $\begin{array}{c}\text { Area } \\
\text { Parkir } \\
\text { Motor }\end{array}$ & Lokasi 3 & $\begin{array}{c}\text { Permainan } \\
\text { Aktif }\end{array}$ & & \\
& & & & \\
\hline
\end{tabular}

Tabel 5. KlasifikasiTipologi Ruang Jalan di Rusunawa Jatinegara Barat

\begin{tabular}{|c|c|c|c|c|}
\hline $\begin{array}{c}\text { Jenis } \\
\text { Ruang }\end{array}$ & Lokasi Ruang & Aktivitas & Tipologi & Dokumentasi \\
\hline $\begin{array}{l}\text { Area } \\
\text { Sirkulasi }\end{array}$ & $\begin{array}{c}\text { Lokasi 1: } \\
\text { Koridor } \\
\text { Rusun }\end{array}$ & $\begin{array}{l}\text { Permainan } \\
\text { Pasif dan Aktif }\end{array}$ & Ruang Jalan & \\
\hline $\begin{array}{l}\text { Sirkulasi } \\
\text { Kendaraan } \\
\text { Bermotor }\end{array}$ & Lokasi 6 & \begin{tabular}{|l} 
Permainan \\
Pasif dan Aktif
\end{tabular} & & \\
\hline $\begin{array}{l}\text { Area } \\
\text { Parkir } \\
\text { Motor }\end{array}$ & $\begin{array}{c}\text { Lokasi 5: Parkir } \\
\text { Rusunawa }\end{array}$ & $\begin{array}{l}\text { Permainan } \\
\text { Pasif dan Aktif }\end{array}$ & & \\
\hline
\end{tabular}

\subsubsection{RUANG ANARKI}

Ruang ini hanya terdapat pada Rusunawa Cigugur. Mitsuru Sendaii mendeskribsikan ruang anarki yaitu ruang yang tidak terdesain, ruang dengan banyak barang-barang rongsokan, ruang disekitar pabrik yang dapat lebih merangsang kreativitas anak-anak dibandingkan ruang lainnya. 
Tabel 5. Klasifikasi Tipologi Ruang Anarki di Rusunawa Cigugur

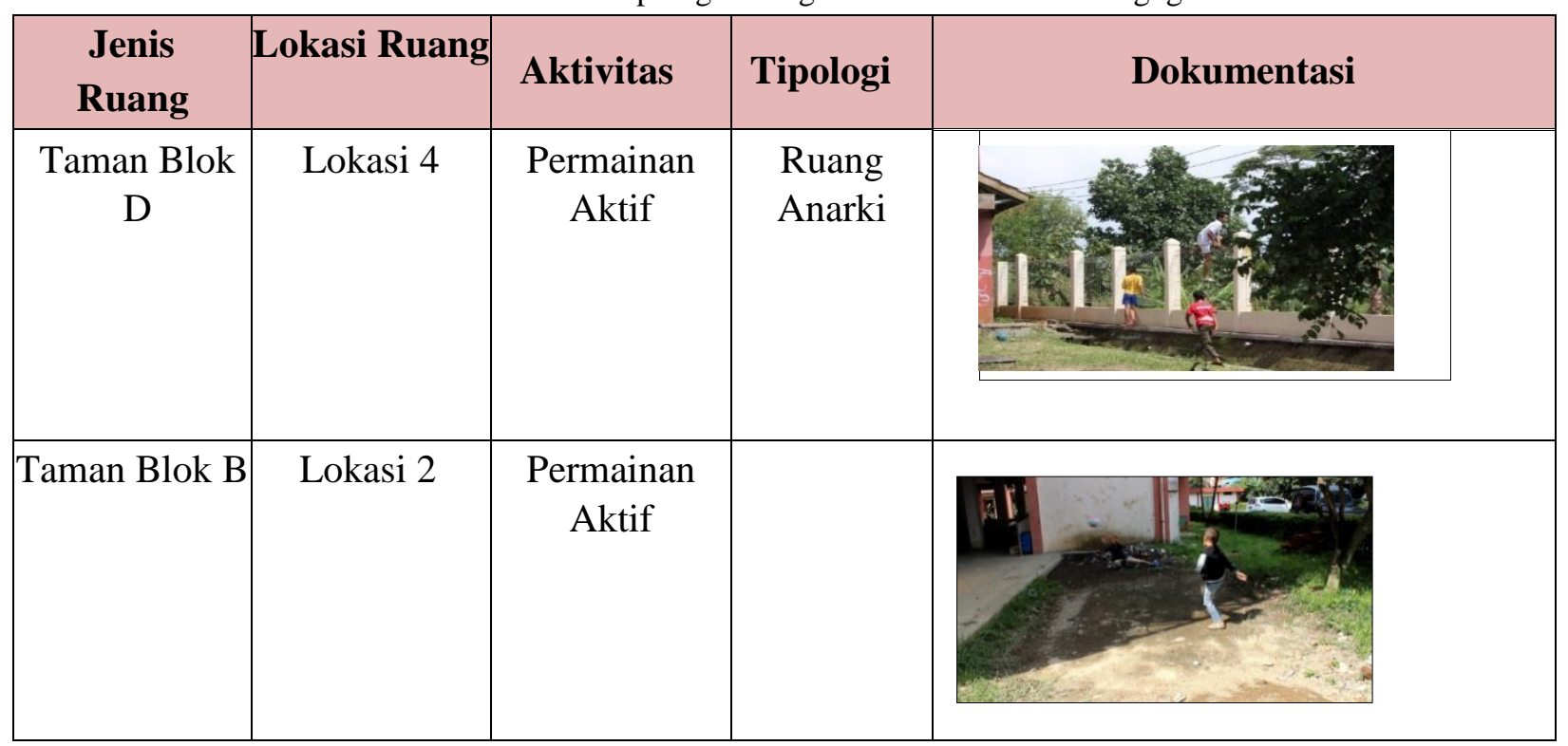

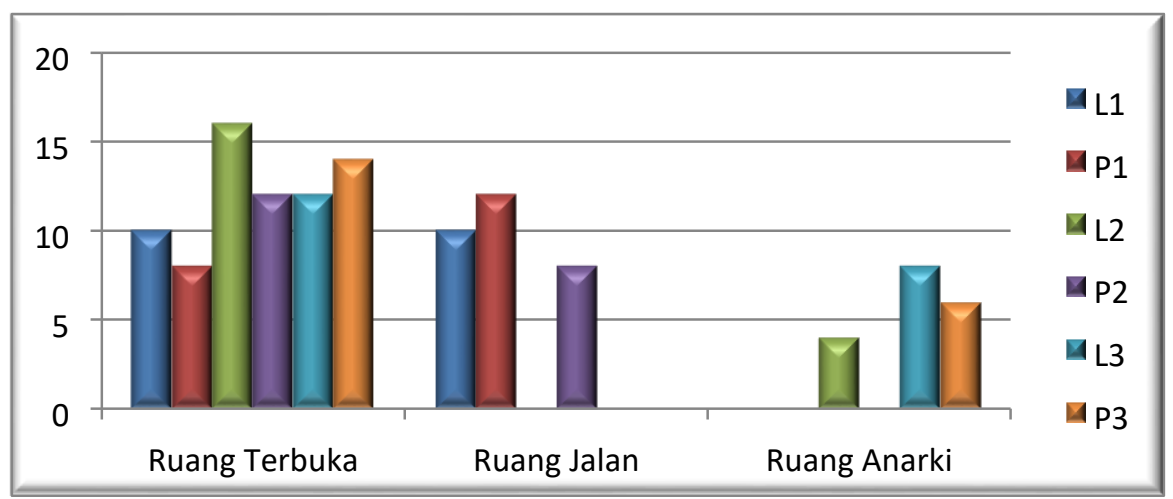

Figur 6. Grafik Jumlah Anak yang Bermain di Masing-masing Ruang 
Tabel 6. Perbandingan Antar Tipologi Ruang

\begin{tabular}{|c|c|c|c|}
\hline Perbandingan & Ruang Terbuka & Ruang Jalan & Ruang Anarki \\
\hline $\begin{array}{l}\text { Berdasarkan } \\
\text { Jumlah Anak }\end{array}$ & \begin{tabular}{lr} 
Area & terbuka \\
merupakan area yang \\
paling disukai & oleh \\
anak-anak. & \\
Karena: & \\
Anak-anak & dapat \\
bermain & tanpa \\
pembatas. & \\
Anak-anak & dapat \\
bermain dalam & skala \\
grup yang besar. \\
Anak-anak & dapat \\
menciptakan & \\
permainan & mereka \\
sendiri, sehingga & \multicolumn{2}{c}{ seatif } \\
melatih sisi & kreatif \\
mereka. &
\end{tabular} & $\begin{array}{l}\text { Ruang jalan } \\
\text { merupakan tipologi } \\
\text { ruang favorit ke-dua } \\
\text { yang dijadikan area } \\
\text { bermain oleh anakanak. } \\
\text { Seperti contohnya } \\
\text { Koridor yang digunakar } \\
\text { oleh anak-anah } \\
\text { perempuan untul } \\
\text { bermain permainan pasi } \\
\text { seperti rumahrumahan } \\
\text { boneka, dll. } \\
\text { Mereka memilih } \\
\text { area ini karena: } \\
\text { Cukup dekat dari } \\
\text { rumahnya. } \\
\text { Mudah dipantau oleh } \\
\text { orang tua } \\
\text { Area tidak ramai, } \\
\text { dan Ternaungi }\end{array}$ & $\begin{array}{l}\text { Pada grafik dapat dilihat } \\
\text { bahwa ruang anarki } \\
\text { bukan menjadi area } \\
\text { favorit untuk bermain. } \\
\text { Area ini lebih dipilih } \\
\text { oleh: } \\
\text { Anak-anak yang sudah } \\
\text { mulai beranjak dewasa. } \\
\text { Pilihan } \\
\text { permainannyapun } \\
\text { lebih menantang } \\
\text { dibandingkan permainan } \\
\text { anak-anak yang } \\
\text { umurnya dibawah } \\
\text { mereka. ini sangat } \\
\text { Area jauh } \\
\text { tersembunyi dan jauh } \\
\text { dari jangkauan orang } \\
\text { tua. }\end{array}$ \\
\hline $\begin{array}{l}\text { Berdasarkan } \\
\text { Home-Range }\end{array}$ & $\begin{array}{r}\text { Home-range dari } \\
\text { masing-masing ruang } \\
\text { terbuka masuk }\end{array}$ & $\begin{array}{l}\text { Ruang jalan seperti } \\
\text { area parkir, lebih } \\
\text { digemari oleh anak }\end{array}$ & $\begin{array}{l}\text { Home-range dari ruang } \\
\text { anarki masuk kedalam } \\
\text { kategori } 0-\end{array}$ \\
\hline & $\begin{array}{l}\text { dalam kategori } 0100 \mathrm{~m} \\
\text { dan 0-250 m. Rasio } \\
\text { umur dan jenis kelamin } \\
\text { terlihat lebih menonjol } \\
\text { kepada anak lakilaki } \\
\text { dengan jenjang umur 9- } \\
12 \text { tahun. } \\
\text { Setelah ditelaah, hal ini } \\
\text { dikarenakan terdapat } \\
\text { dominasi } \\
\text { kelompok. }\end{array}$ & 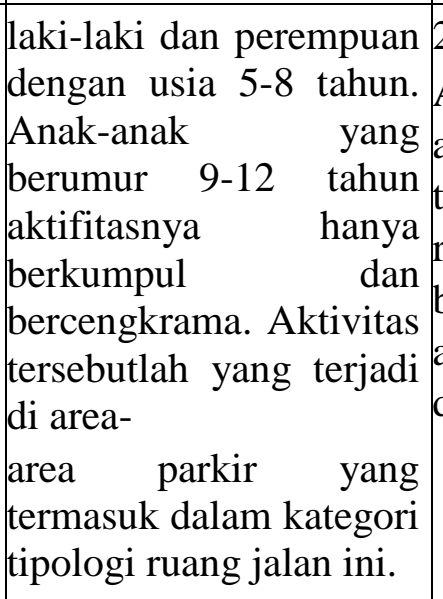 & $\begin{array}{l}\text { 250m dan }>250 \mathrm{~m} . \\
\text { Area ini dijangkau oleh } \\
\text { anak-anak berumur } 9-12 \\
\text { tahun yang membutuhkan } \\
\text { ruang personal yang lebih } \\
\text { besar/luas dibandingkan } \\
\text { anak yang umurnya } \\
\text { dibawah mereka. }\end{array}$ \\
\hline
\end{tabular}




\begin{tabular}{|c|c|c|c|}
\hline $\begin{array}{c}\text { Berdasarkan } \\
\text { Tipe Interaksi } \\
\text { Ruang }\end{array}$ & $\begin{array}{lr}\text { Ruang } & \text { terbuka } \\
\text { merupakan } & \text { ruang } \\
\text { sosiopetal yang mampu } & \text { mewadahi } \\
\text { interaksi } \\
\text { antar orang. Maka dari } \\
\text { itu ruang terbuka } \\
\text { merupakan salah satu } \\
\text { dari ruang sosiopetal, } \\
\text { yang berhasil } \\
\text { menampung aktivitas } \\
\text { bermain anak. }\end{array}$ & $\begin{array}{l}\text { Ruang jalan termasuk } \\
\text { dalam kategori } \\
\text { ruang sosiofugal } \\
\text { yang seharusnya } \\
\text { mampu } \\
\text { mengurangi terjadinya } \\
\text { interaksi. Teori tersebut } \\
\text { tidak terbukti pada } \\
\text { tipologi ruang ini, karena } \\
\text { justru area ini cukup } \\
\text { digemari oleh anak-anak } \\
\text { untuk melakukan } \\
\text { permainan pasif dan } \\
\text { aktif. }\end{array}$ & $\begin{array}{l}\text { Seperti halnya di ruang } \\
\text { jalan, ruang anarki } \\
\text { termasuk dalam kategori } \\
\text { ruang sosiofugal yang } \\
\text { seharusnya mampu } \\
\text { mengurangi terjadinya } \\
\text { interaksi. Teori tersebut } \\
\text { tidak terbukti pada } \\
\text { tipologi ruang ini. }\end{array}$ \\
\hline
\end{tabular}

\subsection{PERBANDINGAN TIPOLOGI RUANG}

\subsubsection{LOKASI 4, DI RUSUNAWA CIGUGUR, CIMAHI, DAN LOKASI 4, DI RUSUNAWA JATINEGARA BARAT}

Tabel 7. Perbandingan Tipologi Lokasi 4 Rusunawa Cigugur dan Lokasi 4 Rusunawa Jatinegara Barat

\begin{tabular}{|l|l|}
\hline \multicolumn{1}{|c|}{ Lokasi 4 Rusunawa Cigugur } & \multicolumn{1}{c|}{ Lokasi 4 Jatinegara Barat } \\
\hline Ruang Anarki & Ruang Terbuka \\
\hline Ruang Sosifugal & Ruang Sosiopetal \\
\hline Skala Grup Kecil & Skala Grup Kecil \\
\hline Tingkat Kenyamanan Rendah & Tingkat Kenyamanan Cukup \\
\hline Tingkat Keamanan Rendah & Tingkat Keamanan Cukup \\
\hline Tidak Ternaungi & Ternaungi \\
\hline
\end{tabular}

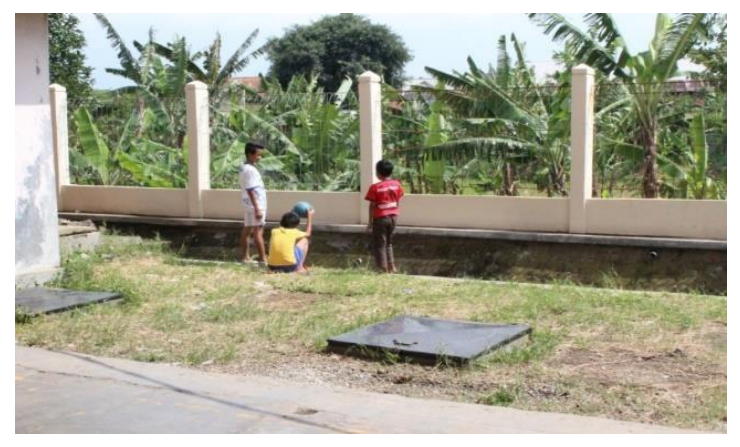

Figur 7. Ruang Sosiofugal di Rusunawa Cigugur yang Menarik Bagii Anak-anak

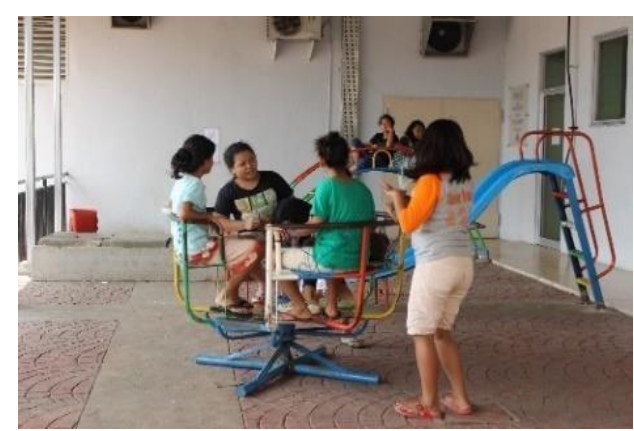

Figur 8. Anak Perempuan Berusia 9-12 Tahun Bermain di Lokasi 4 Rusunawa Jatinegara Barat 
Analisa:

(1) Perbedaan fasilitas yang ada di ruang anarki di Rusunawa Cigugur dengan ruang terbuka di Rusunawa Jatinegara Barat terbukti tidak mempengaruhi aktivitas bermain anak.

(2) Ruang sosiofugal yang terbentuk di Lokasi 4 Rusunawa Cigugur justru menarik minat anak untuk bermain, sementara ruang sosiopetal yang terbentuk di lokasi 4 Rusunawa Jatinegara Barat justru kurang diminati oleh anak-anak.

(3) Anak-anak pada Rusunawa Jatinegara Barat memiliki ruang personal yang jauh lebih tinggi dan lebih luas bila dibandingkan dengan anak-anak di Rusunawa Cigugur.

(4) Dominasi kelompok cenderung berpengaruh kuat pada pola aktivitas bermain anak.

\subsubsection{LOKASI 6, DI RUSUNAWA CIGUGUR, CIMAHI, DAN LOKASI 3, DI RUSUNAWA JATINEGARA BARAT}

Tabel 9. Perbandingan Tipologi Lokasi 6 Rusunawa Cigugur dan Lokasi 3 Rusunawa Jatinegara Barat

\begin{tabular}{|l|l|}
\hline \multicolumn{1}{|c|}{ Lokasi 6 Rusunawa Cigugur } & \multicolumn{1}{c|}{ Lokasi 3 Jatinegara Barat } \\
\hline Ruang Terbuka & Ruang Jalan \\
\hline Ruang Sosifugal & Ruang Sosiopetal \\
\hline Skala Grup Besar & Skala Grup Besar \\
\hline Tingkat Kenyamanan Cukup & Tingkat Kenyamanan Cukup \\
\hline Tingkat Keamanan Rendah & Tingkat Keamanan Rendah \\
\hline Ternaungi & Ternaungi \\
\hline Berlokasi di Lantai Dasar Rusun & Berlokasi di Lantai Dasar Rusun \\
\hline
\end{tabular}

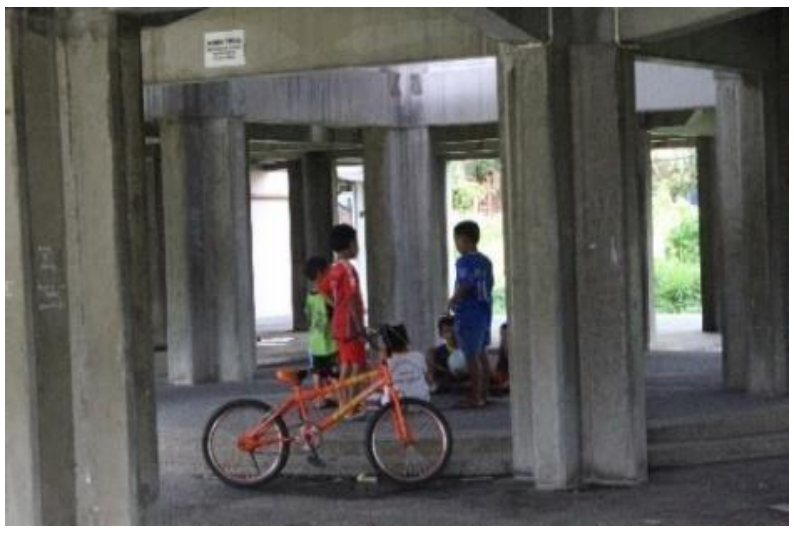

Figur 9. Anak-anak Bermain Sepeda di Lokasi 6 Rusunawa Cigugur

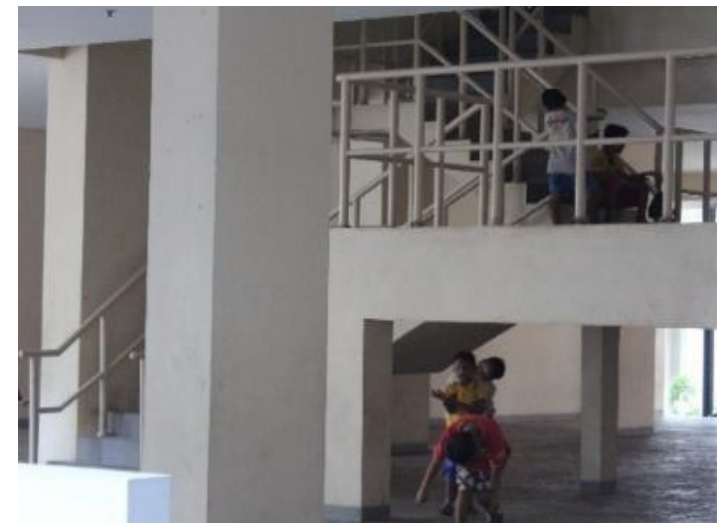

Figur 10. Anak-anak Bermain di Dekat Raling Tangga 
Analisa:

(1) Pada kedua titik ini dapat dilihat bahwa, area yang berciri fisik ruang yang sama dapat berpotensi lebih besar untuk menghasilkan aktivitas bermain yang sama pula.

(2) Walaupun jenis ruang di lokasi 6 Rusunawa Cigugur adalah anarki aktivitas yang tercipta sejenis dengan yang tercipta di ruang jalan di lokasi 3 Rusunawa Jatinegara Barat.

\subsubsection{LOKASI 1: KORIDOR RUSUNAWA CIGUGUR, CIMAHI DAN LOKASI 1 : KORIDOR RUSUNAWA JATINEGARA BARAT}

Tabel 8. Perbandingan Tipologi Lokasi 1 Rusunawa Cigugur dan Lokasi 1 Rusunawa Jatinegara Barat

\begin{tabular}{|l|l|}
\hline \multicolumn{1}{|c|}{ Lokasi 1 Rusunawa Cigugur } & \multicolumn{1}{c|}{ Lokasi 1 Jatinegara Barat } \\
\hline Ruang Jalan & Ruang Jalan \\
\hline Ruang Sosifugal & Ruang Sosiofugal \\
\hline Skala Grup Kecil & Skala Grup Kecil \\
\hline Tingkat Kenyamanan Rendah & Tingkat Kenyamanan Cukup \\
\hline Tingkat Keamanan Rendah & Tingkat Keamanan Cukup \\
\hline Ternaungi & Ternaungi \\
\hline
\end{tabular}

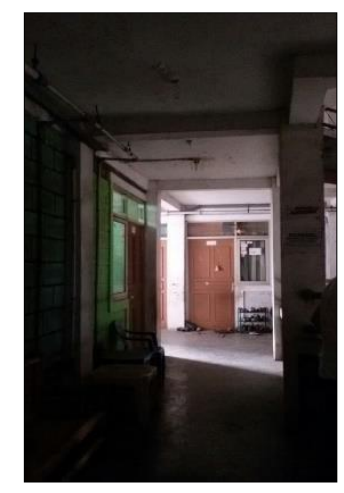

Figur 11. Koridor Rusunawa Cigugur Gelap dan Lembab

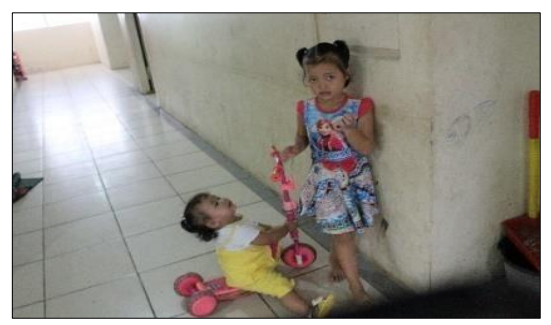

Figur 12. Anak Bermain Otoped di Koridor Jatinegara Barat

Analisa:

(1) Di koridor Rusunawa Cigugur yang gelap dan lembab aktivitas bermain anak sangat minim bahkan cenderung nihil, sementara aktivitas di koridor di Rusunawa Jatinegara Barat yang terang dan bersih jauh lebih ramai.

(2) Pada Rusunawa Cigugur, terdapat void ditengah bangunan sementara pada Rusunawa Jatinegara Barat seluruh bukaan ditutupi dengan teralis besi.

(3) Hal ini dapat disimpulkan bahwa, orang tua mempertimbangkan tingkat kenyamanan dari area bermain anak. 


\subsubsection{LOKASI 5 DI RUSUNAWA CIGUGUR, CIMAHI DAN LOKASI 2 DI RUSUNAWA JATINEGARA BARAT, JAKARTA TIMUR}

Tabel 9. Perbandingan Tipologi Lokasi 5 Rusunawa Cigugur dan Lokasi 2 Rusunawa Jatinegara Barat

\begin{tabular}{|l|l|}
\hline \multicolumn{1}{|c|}{ Lokasi 5 Rusunawa Cigugur } & \multicolumn{1}{c|}{ Lokasi 2 Jatinegara Barat } \\
\hline Ruang Terbuka & Ruang Terbuka \\
\hline Ruang Sosiopetal & Ruang Sosiopetal \\
\hline Skala Grup Besar & Skala Grup Besar \\
\hline Tingkat Kenyamanan Cukup & Tingkat Kenyamanan Cukup \\
\hline Tingkat Keamanan Cukup & Tingkat Keamanan Cukup \\
\hline Ternaungi & Tidak Ternaungi \\
\hline
\end{tabular}

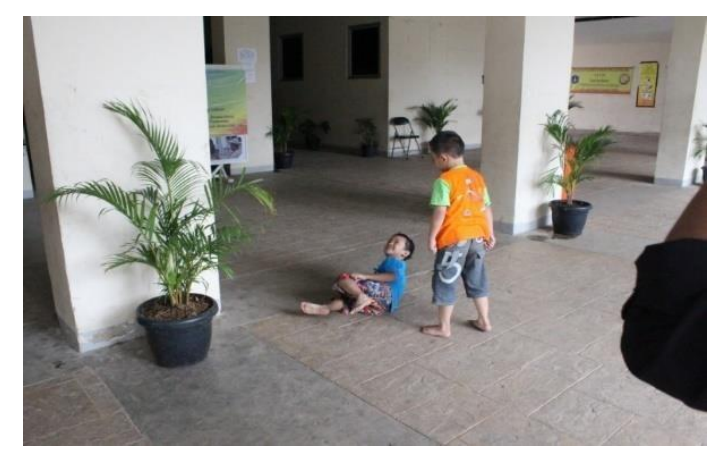

Figur 13. Anak Terjatuh Ketika Bermain Bola di Rusunawa Jatinegara Barat

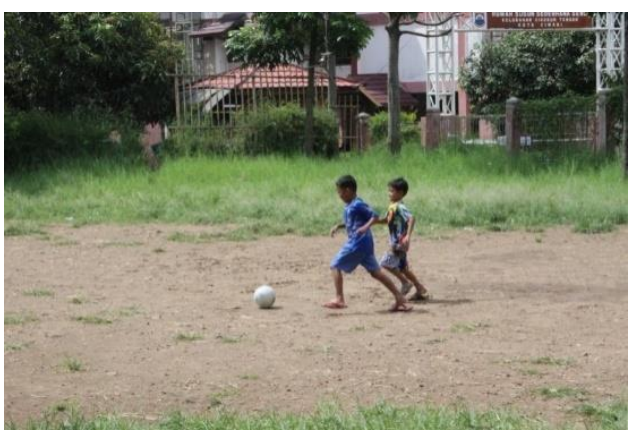

Figur 14. Anak Bermain Bola di Lokasi 2 Rusunawa Cigugur

Analisa:

(1) Permainan pasif dan aktif yang tercipta diantara dua lokasi ini sama.

(2) Contohnya saja permainan aktif yang dominan tercipta di kedua lokasi ini adalah sepak bola. Kedua area ini juga lebih digemari oleh anak laki-laki dengan rentang umur 5-8 dan 9-12 tahun.

\subsubsection{LOKASI 3 DI RUSUNAWA CIGUGUR, CIMAHI DAN LOKASI 5: AREA PARKIR MOTOR DI RUSUNAWA JATINEGARA BARAT, JAKARTA TIMUR}

Tabel 10. Perbandingan Tipologi Lokasi 3 Rusunawa Cigugur dan Lokasi 5 Rusunawa Jatinegara Barat

\begin{tabular}{|l|l|}
\hline \multicolumn{1}{|c|}{ Lokasi 3 Rusunawa Cigugur } & \multicolumn{1}{c|}{ Lokasi 5 Jatinegara Barat } \\
\hline Ruang Terbuka & Ruang Terbuka \\
\hline Ruang Sosiofugal & Ruang Sosiofugal \\
\hline
\end{tabular}




\begin{tabular}{|l|l|}
\hline Skala Grup Kecil & Skala Grup Besar \\
\hline Tingkat Kenyamanan Rendah & Tingkat Kenyamanan Rendah \\
\hline Tingkat Keamanan Rendah & Tingkat Keamanan Rendah \\
\hline Ternaungi & Tidak Ternaungi \\
\hline
\end{tabular}

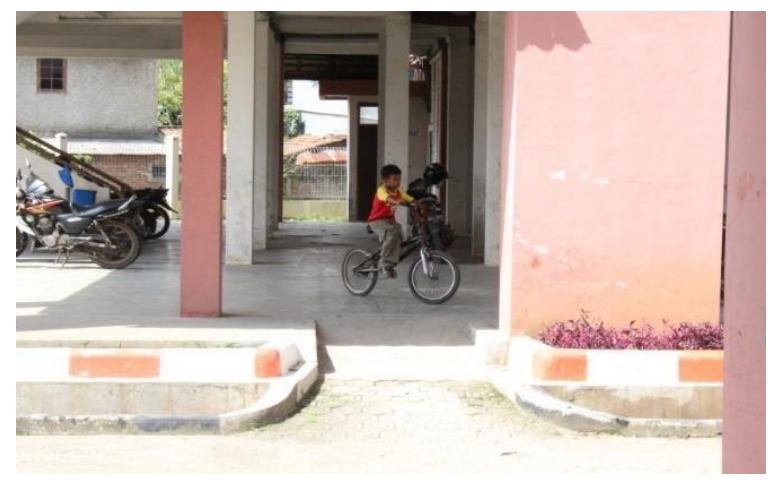

Figur 15. Anak Bermain Sepeda di Lokasi 3 di Rusunawa Cigugur

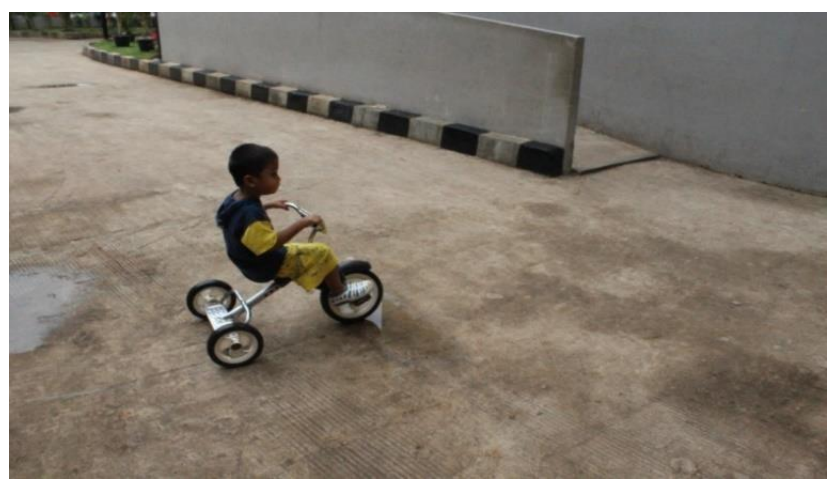

Figur 16. Anak Bermain Sepeda di Lokasi 5 di Rusunawa Jatinegara Barat

Analisa:

(1) Kedua ruang yang masuk dalam ruang sosiofugal walaupun ramai dilalui kendaraan bermotor, area ini merupakan salah satu area yang tingkat aktivitas bermainnya paling tinggi dikalangan anak berusia 5-8 tahun dan 9-12 tahun.

(2) Seting fisik yang ada di masing-masing ruang tidak berpengaruh terhadap aktivitas bermain anak, dapat dilihat bahwa aktivitas yang terjadi sama.

\subsection{DASAR-DASAR PENGELOMPOKAN AKTIVITAS BERMAIN ANAK}

Setelah dilakukan pengamatan di kedua rusunawa, terdapat hal-hal yang mempengaruhi terbentuknya kelompok-kelompok bermain, yang didasarkan pada pengelompokan menurut Altman. Diantaranya, yaitu:

\section{(1) Umur dan Jenis Kelamin}

Umur dan jenis kelamin merupakan faktor yang paling utama dalam pembuatan kelompok-kelompok bermain. Menurut Altmansalah satu kemungkinan terjadi pengelompokkan pada kelompok bermain karena dipengaruhi oleh ruang personal, yaitu jenis kelamin dan umur yang lebih disebabkan oleh perbedaan dalam sosialisasi antara pria dan wanita daripada karena perbedaan biologis. Altman juga mengatakan bahwa semakin bertambahnya umur seseorang personal space yang dibutuhkan juga akan semakin meluas.

\section{(2) Organisasi}

Organisasi adalah sekelompok orang yang secara formal mempunyai suatu keterkaitan dipersatukan dalam suatu kerjasama untuk mencapai tujuan. Dalam studi kasus, organisasi yang terdapat tidak secara langsung mempengaruhi perilaku aktivitas bermain pada anak,namun kedekatan antar orang tua anak dalam struktur organisasi juga mendekatkan hubungan anakanaknya.

\section{(3) Struktur Kelompok}


Kecocokan lingkungan tidak akan bisa tercapai apabila tidak adanya sekelompok orang. Semakin besar kelompok bermain seorang anak semakin luas juga wilayah bermainnya.

\section{(4) Hubungan Sosial}

Hubungan sosial yang terjadi di rusunawa merupakan cerminan dari karateristik warga kampung pada umumnya, karena kebanyakan warga rumah susun biasanya berasal dari program relokasi pemerintah. Karateristik mereka sendiri dapat dilihat memiliki hubungan sosial yang baik dan erat antar satu sama lain. Hal tersebut juga terjalin didalam pertemanan anak-anak penghuni rusunawa ini.

\section{(5) Tingkatan Hidup}

Tingkatan hidup sangat mempengaruhi kualitas ruang yang dibutuhkan seseorang. Tingginya tingkatan hidup seseorang akan menuntut kualitas dan kenyamanan ruang yang lebih tinggi lagi. Dalam studi kasus, tingkatan hidup warga dapat disebut menengah kebawah atau rendah.

\section{(6) Gaya Hidup}

Menurut Stanley Milgram, gaya hidup seseorang dapat mempengaruhi karater fisik arstitektur tempat-tempat yang diketahui dan dikunjunginya.

Warga Rusunawa Jatinegara Barat dan Rusunawa Cigugur keduanya mayoritas memiliki gaya hidup sederhana. Gaya hidup tersebut berpengaruh kepada aktivitas permainan yang dipilih oleh anak-anaknya. Contohnya saja, anak perempuan yang ingin bermain masakmasakan lebih memilih dedaunan atau gundukan tanah sebagai "bahan masakan" mereka, dari hal tersebut bisa dilihat bahwa anak-anak ini memiliki tingkat kreatifitas yang tinggi karena keterbatasan permainan yang mereka miliki.

\section{(7) Aktivitas Dasar}

Aktivitas dasar merupakan aktivitas utama yang sering dilakukan. Anak-anak di Rusunawa Jatinegara Barat dan Rusunawa Cigugur memiliki aktivitas dasar yaitu belajar di sekolah. Aktivitas ini jelas berpengaruh kepada pola aktivitas yang terjadi. Contohnya saja, pada pukul 810 pagi dapat dilihat bahwa titik-titik lokasi area bermain terlihat sepi karena anak-anak penghuni rusunawa masih dalam jam sekolah. Baru di sore hari titik-titik lokasi bermain mulai ramai karena anak-anak sudah pulang sekolah.

\subsection{KONSEP SISTEM AKTIVITAS BERMAIN ANAK}

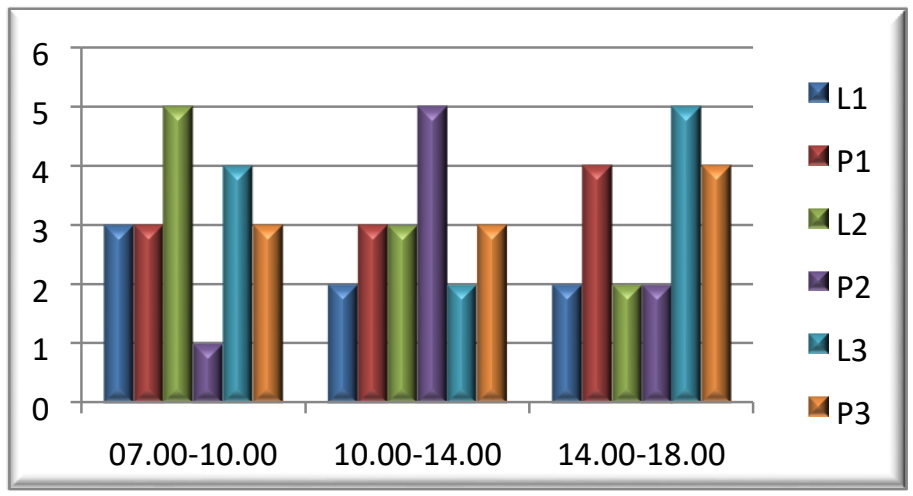

Figur 17. Grafik Sistem Aktivitas Bermain Anak Warga di Rusunawa Cigugur 


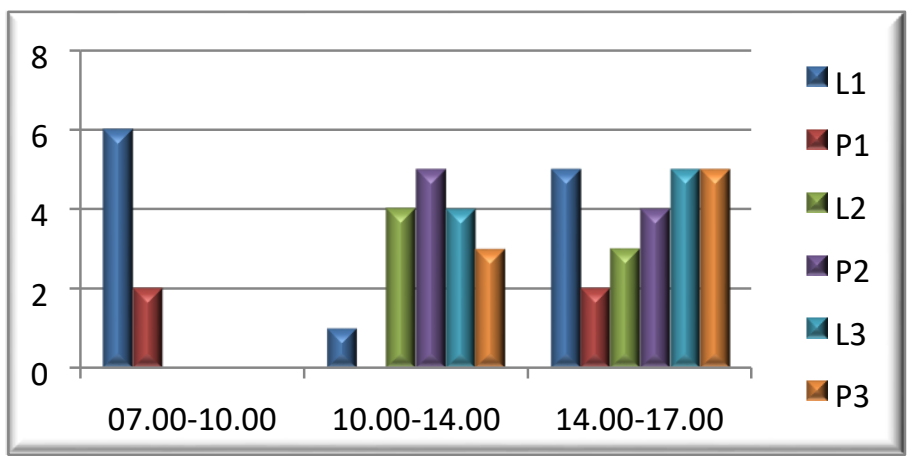

Figur 18. Grafik Sistem Aktivitas Bermain Anak Warga di Rusunawa Jatinegara Barat

Grafik di atas memperlihatkan sistem aktivitas bermain paling sering dilakukan oleh seluruh kelompok anak-anak warga adalah pada periode waktu sore hari atau sekitar pukul 14.0018.00 karena berbagai faktor yang mempengaruhi baik faktor psikologis maupun faktor fisik lingkungan.

Faktor psikologis yang mempengaruhinya antara lain seperti sudah berakhirnya aktivitas sekolah mayoritas anak-anak warga sehingga, mempengaruhi jumlah teman yang dapat bermain di waktu tersebut.

Faktor fisik lingkungan yang mempengaruhi antara lain seperti kondisi cuaca di waktu tersebut yang mempengaruhi jenis permainan dan tempat bermainnya serta kedekatan anak-anak sebagai pelaku permaianan dengan tempat bermainnya.

\subsection{KONSEP SETING PERILAKU AKTIVITAS BERMAIN ANAK}

Dalam studi kasus, seting perilaku merupakan rangkaian sistem yang terjadi ketika ruang aktivitas bermain anak terbentuk secara alami mengikuti kondisi fisik yang telah ada di area komplek rumah susun. Selain itu, seting perilaku tidak membatasi pelaku permainannya. Pelaku aktivitas dapat digantikan dan mengalami perubahan. Hal yang terpenting adalah selama posisi pelaku permainan dapat diisi dan aktivitas bermain dapat tetap berlangsung.

Area ruang aktivitas bermain anak yang terdapat di kasus studi menunjukan bahwa ruang yang tidak direncakan dapat menjadi ruang aktivitas bermain anak-anak warga karena adanya kemampuan yang sesuai dengan keinginan anak-anak. Ruang aktivitas bermain anak dalam kasus ini membentuk tipologi ruang dan disebut sebagai ruang informal karena ruang tersebut terbentuk dengan spontan, hanya pada waktu tertentu, tidak tetap dan diluar kesadaran anak-anak yang bermain disana.

Konsep sistem aktivitas dan seting ruang aktivitas bermain anak di Rusunawa Jatinegara Barat dan Rusunawa Cigugur juga menunjukan bahwa lingkungan merupakan pertimbangan utama dalam perancangan ruang aktivitas bermain anak dibandingkan persepsi tata dan tipe ruang secara spesifik. Hal ini disebabkan karena lingkungan dapat memberi citra terhadap kesesuaian lingkungan dengan pola perilaku penggunanya yang merupakan satu kesatuan yang sesuai dan harmonis. 


\section{KESIMPULAN}

Dapat disimpulkan bahwa, perbedaan yang terdapat pada pola aktivitas bermain anak pada Rusunawa Jatinegara Barat dan Rusunawa Cigugur tidak disebabkan jangkauan bermain anak yang semakin menjauh, justru karena faktor dominasi yang berperan besar sehingga membuat kelompok-kelompok yang lebih kecil, menyingkir dan mencari tempat bermain lain.

Bila diperbandingkan antar masing-masing rusun didapatkan bahwa pola aktivitas bermain anak di Rusunawa Jatinegara Barat dan Rusunawa Cigugur dipengaruhi oleh faktor yang sama antara lain organisasi, struktur kelompok, hubungan sosial, tingkatan hidup, gaya hidup, aktivitas dasar, jenis kelamin dan usia anak.

Pola aktivitas juga terpengaruh dengan ruang personal (personal space) anak. Di kedua rusun ditemukan bahwa, bertambahnya usia seorang anak ia akan semakin membutuhkan ruang personal yang lebih luas.

Terdapat 6 titik area bermain di Rusunawa Jatinegara Barat, Jakarta Timur dan 8 titik di Rusunawa Cigugur, Cimahi. Lokasi tersebut diklasifikasikan menjadi beberapa tipologi ruang, seperti ruang jalan, ruang terbuka dan ruang anarki. Rusunawa Jatinegara Barat memiliki 3 ruang terbuka, 3 ruang jalan. Sementara Rusunawa Cigugur memiliki 2 ruang terbuka, 3 ruang jalan dan 2 ruang anarki.

Tipologi area bermain yang paling digemari oleh anak adalah ruang terbuka Anak-anak dari umur 2-4 tahun, 5-8 tahun dan 9-12 tahun umumnya lebih menyukai bermain di areaarea terbuka. Karena, di ruang terbuka mereka bisa bermain dalam skala grup yang besar, dan mereka dapat berlatih untuk mengeksplor dirinya lebih jauh dalam hal kreatifitas untuk menciptakan permainannya sendiri.

Jadi dapat disimpulkan bahwa, tidak terdapat perbedaan pola perilaku aktivitas bermain anak di antara kedua rusun. Bila dibandingkan antar ruang/tipologi memang akan tercipta aktivitas permainan yang berbeda, tetapi bila diperbandingkan antara tipologi ruang di masingmasing Rusunawa yang sama, maka akan menghasilkan pola perilaku aktivitas bermain yang sama pula.

\section{DAFTAR PUSTAKA}

Hurlock, Elizabeth, B. (1978). Child Development, Sixth Edition. New York: Mc. Graw Hill, Inc. Laurens, Joyce Marcella. (2004). Arsitektur dan Perilaku Manusia. Surabaya: Grasindo. Wohlwill, Joachim F (1981), The Physical Environment and Behavior.New York: Plenum Press. Altman, Irwin \& Stokol Daniel (1987). Handbook of Environmental Psychology. New York: Jon Wiley \& Sons, Inc.

Milgram, Stanley (2009). Understanding Obedience and Its Implications. New York: Palgrave Macmillan.

Cooper, Clare. (2013). Therapeutic Landscapes: An Evidence-Based Approach to Designing Healing Gardens and Restorative Outdoor Spaces. New York: John Wiley \& Sons Inc.

Hall, Edward (1966). The Hidden Dimension. New York: Garden City. 